\title{
The Robustness of EU Financial Crimes Legislation: A Critical Review of the EU and UK Anti-Fraud and Money Laundering Scheme
}

By Ester Herlin-Karnell* \& Nicholas Ryder ${ }^{+}$

\section{Introduction}

In this paper we set out to chart the European Union's (EU) genesis of fighting crime as partly one of establishing the EU as an "Area of Freedom, Security and Justice" (AFSJ) and partly one of facilitating the EU internal market creation and the establishment of a global market place. We provide an overview of the current complexities facing the EU in its current struggles for a reformation and against statist approaches by focusing on the law on financial crimes and its contemporary challanges. When viewed in an historical perspective the EU's tactic in the fight against financial crimes appears to depart from the classic internal market-based formula of the removal of obstacles for market creation and thereby ventures into the EU criminal law domain with all of its inherent complexities, without an adequately matured legal framework to endorse its policies from within. Second, to the extent that the EU adopts the market theory template in the EU policy area of 'Freedom, Security and Justice', there are global elements

\footnotetext{
*University Research Chair of EU Constitutional Law and Justice, VU Amsterdam.

+ Professor of Financial Crime, Department of Law, Faculty of Business and Law, University of the West of England, Bristol.
} 
to the EU's sanction policies. These features confirm a hybridity in which legal sources are interacting within the AFSJ field. We aim to critically assess the current state of play of the regulation of financial crimes in the contemporary EU. Furthermore, the paper focuses on recent developments in the area of financial crimes by looking at the framework for EU anti-fraud legislation: OLAF, the proposed EU Public prosecutor, the function of Eurojust and the proposed Directive of the European Parliament and of the Council on the fight against fraud to the Union's financial interests by means of criminal law. Specifically, we discuss the way the Fourth AntiMoney Laundering Directive came about and if, as claimed by the EU itself, it equips the EU with the right legal toolkit for fighting money laundering and terror financing. We also set out to scrutinize the constitutional implications of an increased powers vested in the EU Agencies in this area as powerful players for EU enforcement and we discuss the question of accountability as well as the problem of a human rights deficit in this area. We end however on a happier note by looking at the judiciaries concern to maintain individual data protection and the EU Court of Justice as a guarantee of proportionality and reasonableness in European legislative action. 


\section{The "Area of Freedom, Security and Justice" and the fight against financial crimes: from OLAF to a European Public Prosecutor}

The EU's fight against financial crimes takes place at multiple levels in the EU regulatory machinery: both within the framework and endeavor of the establishment of an "Area of Freedom, Security and Justice" and within the traditional playing field of the EU internal market and the need to ensure market integrity. Furthermore, the EU and the Member States are required by the Treaty on the Functioning of the EU (TFEU, Article 325) to counter fraud and any other illegal activities affecting the financial interests of the EU.

While much has been said about the purpose of fighting financial crimes within the internal market ${ }^{1}$, much less has been said with regard to the impact of these findings on the operation of the crime fighting project of the AFSJ. ${ }^{2}$ So while the internal market objectives are well dissected this is different in the AFSJ in the context of financial crimes legislation. We argue that this is a mistake if one truly wants to understand the EU's fight against

\footnotetext{
${ }^{1}$ See e.g. C Stefanou and $\mathrm{H}$ Xhanthaki Financial Crime In the EU (Kluwer law international 2005).

${ }^{2}$ For an attempt to look at the AFSJ in this context see, E Herlin-Karnell 'Constructing Europe's Area of Freedom, Security, and Justice through the Framework of "Regulation": A Cascade of Market-Based Challenges in the EU's Fight Against Financial Crime', (2015), German Law Journal 171
} 
irregularities in the internal market. After all, the AFSJ embodies a complicated hybrid system of interacting norms (global, EU and national) and should therefore be understood in the light of the classic EU law policy of the internal market. In short, the AFSJ deals with, inter alia, security issues, border control, anti-terrorism law and crime. While market creation has always been focused on principally justifying aims of the Union's increased powers and curtailment of Member State competences, ${ }^{3}$ the EU's rulemaking powers - when applied outside the traditional context of the internal market-ask pressing questions. They ask not just how far national sovereignty can be overturned by other concerns, such as the need for the construction of the EU market, but also its interaction with the EU's expanding security agenda and the role of fundamental rights protection. As a result of the Lisbon Treaty changes, though, financial crimes now form a specific part of the competences that are granted to the EU under Article 83 TFEU, posing the question of whether the EU will go down the AFSJ path or if it should stick to its traditional way of resorting to Article 114 TFEU. After all, Article 114 TFEU allows for a more expansive use of EU competences-as interpreted by the Court of Justice-way of reasoning as well as for the adoption of Regulations (which is more restricted under 83 TFEU which prescribes the use of Directives).

\footnotetext{
${ }^{3}$ See, e.g., M Egan, Constructing a European market: standards regulation, and governance (OUP 2001).
} 
Therefore, although financial regulation is an objective of the internal market, any financial regulation that involves criminal law responses to fight irregularities within the internal market trespasses on the turf of the AFSJ. Therefore, what is at stake here is, obviously, also a question of competence and a choice of the correct legal basis. The Fourth Money Laundering Directive discussed below seems to confirm the view that the EU will stick to the market theory model rather than (only) switching to a criminal law model within the AFSJ. ${ }^{4}$ Therefore, we are faced with the classic choice-of-legal-basis question where Article 83 TFEU is lex specialis if the measure in question is primarily a criminal law measure. Therefore, under the present Treaty framework there are good reasons to believe that the center of gravity test will point in the direction of more general internal market powers. Thus, "mainstream" internal market powers, such as Article 114 TFEU, are still of crucial importance and are particularly significant with respect to the impact in the national arena as this provision also allows for the adoption of regulations - thereby having a direct impact on citizens. From a Member State perspective, there is merit with respect to engaging Article 83(2) TFEU as compared to action taken under Article 114 TFEU, in that this provision grants the possibility for the Member States to pull an

\footnotetext{
${ }^{4}$ Directive of the European Parliament and of the Council on the Prevention of the Use of the Financial System for the Purpose of Money Laundering and Terrorist Financing, Directive (EU) 2015/849
} 
emergency brake if a proposed measure appears to be too sensitive for the national criminal law system. Moreover, the use of Article 114 or Article 325 TFEU (anti-fraud rules) would mean that the United Kingdom (UK), Ireland, and Denmark would not be granted the "cherry-pick" possibility of opt-outs as they otherwise would regarding legislation within the AFSJ (in accordance with Protocol 21 and Protocol 22). ${ }^{5}$

Yet the importance of fighting financial irregularities against the EU is however far from a new endeavor when, most importantly, one considers the powers of the European Anti-Fraud Office, OLAF. It concentrates on frauds committed against the EU, and it doesn't impose any anti-fraud obligations on member states. ${ }^{6}$ The origins of its strategy can be traced to the creation of the Common Agricultural Policy which resulted in the number of allegations of fraud increasing. ${ }^{7}$ However, it was not until the 1970s that the EU began to realize the threat to its finances posed by

\footnotetext{
${ }^{5}$ Treaty of Lisbon Amending the Treaty on European Union and the Treaty Establishing the European Community, Dec. 13, 2007, 2007 O.J. (C 306) (citing Protocol 21 attached to the Lisbon Treaty). According to Articles 1 and 3 of Protocol 21 attached to the Lisbon Treaty, the UK and Ireland do not take part in legislation adopted within the AFSJ unless they opt to participate in such legislation by notifying the President of the Council in writing within three months after a proposal or initiative has been presented to the Council. Id. Protocol 22 grants Denmark a complete opt out from the AFSJ.

${ }^{6}$ See for example the EUs Convention on the Protection of the ECs financial interests [O] C 316, 27.11.1995] and the EU's 2001 Framework Decision 'combating fraud and counterfeiting of non-cash means of payment'.

${ }^{7}$ D Ruimschotel,. (1994), 'The EC budget: ten percent fraud? A policy analysis approach', Journal of Common Market Studies, 32(3), 320-342, at 320.
} 
fraud. ${ }^{8}$ Therefore, it is needed to briefly set out the EU path towards the current 'tough on financial crimes' approach.

An important part of the EU's fraud policy is of course the European Court of Auditors, which acts as an independent reviewer of the EU's finances and which has played an important role in the history of EU anti-fraud measures. ${ }^{9}$ It determines whether any fraud has been committed against the $\mathrm{EU}$ and identifies whether or not the fiscal procedures have been recorded, properly implemented in lawful method to guarantee efficiency and effectiveness. ${ }^{10}$ The Court of Auditors has highlighted instances of fraud on several occasions to the European Parliament, ${ }^{11}$ however, their

${ }^{8}$ C Pujas,. (2003). 'The European Anti-Fraud Office (OLAF): a European policy to fight against economic and financial fraud?', Journal of European Public Policy, 10(5), 778-797, at 780. The amount of fraud committed against the EU is impossible to determine, yet recent estimates suggest that the figure on an annual basis is $€ 1,000,000,000$. See $H$ Xanthaki,. (2010), 'What is EU fraud? And can OLAF really combat it?', Journal of Financial Crime, 17(1), 133-151, at 133,

${ }^{9}$ The European Court of Auditors was established by the Treaty of Brussels in 1975. For a more detailed discussion about the general role of the European Court of Auditors see Quirke, B. and Pyke, C. (2002), 'Policing European Union Expenditure A Critical Appraisal of the Transnational Institutions', Journal of Finance and Management in Public Services, 2(1), 21-32, at 23-25.

10 European Court of Auditors (n/d), 'About us', available at http://eca.europa.eu/portal/page/portal/aboutus (accessed 3 August 2010).

${ }^{11}$ Pujas, C. (2003), 'The European Anti- Fraud Offi ce (OLAF): a European policy to fight against economic and fi nancial fraud?', Journal of European Public Policy, 10(5), 778-797, at 780 . The amount of fraud committed against the EU is impossible to determine, yet recent estimates suggest that the fi gure on an annual basis is $€ 1000000000$. See Xanthaki, H. (2010), 'What is EU fraud? And can OLAF really combat it?', Journal of Financial Crime, 17(1), 133-151, at 133. 
efforts have been hampered because they are not entitled or allowed to undertake any anti-fraud investigations. ${ }^{12}$ The European Parliaments Committee of Budgetary Control who recommended that a 'flying squad' should be created to investigate allegations of fraud raised this problem. ${ }^{13}$ As a result, 'Unite Co-ordination de la lute anti-fraude', (UCLAF) was established in 1987 and became operational in 1988, with the objective of dealing with fraud against the EU. ${ }^{14}$ UCLAF was created as a result of an increase in financial irregularities within the $\mathrm{EU}$ and the resulting criticism. ${ }^{15}$ Its effectiveness was limited due to its small number of "desk bound" staff ${ }^{16}$ and its disorganised structure. ${ }^{17}$ Both of which inhibited its ability to effectively investigate fraud. ${ }^{18}$ UCLAF's position became precarious following the reported loss of $f 600 \mathrm{~m}$ of humanitarian aid to fraudulent

\footnotetext{
12 Ibid.

${ }^{13}$ White, S. (1999), 'Investigating EC Fraud: The metamorphosis of UCLAF', Journal of Financial Crime, 6(3), 255-260, at 256.

${ }^{14}$ Tupman, B. (2000), 'The sovereignty of fraud and the fraud of sovereignty: OLAF and the wise men', Journal of Financial Crime, 8(1), 32-46, at 43.

${ }^{15}$ Quirke, B. (2007), 'Critical appraisal of the role of UCLAF', Journal of Financial Crime, 14(4), 460-473, at 460. Tupman also noted that UCLAF was the European Commission's "response to a picture is emerging of criminal networks slimming down, specialising and becoming more and more market responsive". See Tupman, W. (1994), 'You Should Have Read the Small Print: The European Commission's Post-Maastricht Response to Fraud', Journal of Financial Crime, 2(2) 107-114, at 107.

${ }^{16}$ White above, $\mathrm{n} 49$ at 256.

${ }^{17}$ Pujas, C. (2003), 'The European Anti- Fraud Offi ce (OLAF): a European policy to fight against economic and fi nancial fraud?', Journal of European Public Policy, 10(5), 778-797, at 781. See in particular Doig, A. (1996). 'A fragmented organizational approach to fraud in a European context', European Journal on Criminal Policy and Research, 3(2), 48-73.

18 B Tupman, . (2000), 'The sovereignty of fraud and the fraud of sovereignty: OLAF and the wise men', Journal of Financial Crime, 8(1), 32-46, at 43.
} 
activities. ${ }^{19}$ The Court of Auditors recommended the establishment of an autonomous anti-fraud agency and ${ }^{20}$ OLAF, was born in $1999 .{ }^{21}$ OLAF's objective was to assist EU institutions to combat fraud and other financial indiscretions. ${ }^{22}$ OLAF is responsible for the "fraud-proofing of EU legislation", ${ }^{23}$ and it has the ability to conduct administrative investigations, ${ }^{24}$ which are defined as inspections and other appropriate measures performed by OLAF staff to determine the quality of the allegation under investigation. There are two types of investigations internal and external. Internal investigations relate to the fina ncial in

${ }^{19}$ B Quirke, B. and C Pyke,. (2002), 'Policing European Union Expenditure: A Critical Appraisal of the Transnational Institutions', Journal of Finance and Management in Public Services, 2(1), 21-32, at 23-25.

${ }^{20}$ B Quirke, (2010), 'OLAF's role in the fight against EU Fraud: Do too many cooks spoil the broth?' Crime, Law and Social Change, 53(1), 97-108, at 97. White, S. (1999), 'Investigating EC Fraud: The metamorphosis of UCLAF', Journal of Financial Crime, 6(3), 255-260, at 257. In particular, White stated that the Court of Auditors "recommended that consideration should be given to the establishment of a separate unit, to which any suspicion of corruption would automatically be communicated and which would have the authority and resources to undertake any necessary investigation".

${ }^{21}$ Pujas, C. (2003), 'The European Anti- Fraud Offi ce (OLAF): a European policy to fight against economic and financial fraud?', Journal of European Public Policy, 10(5), 778-797, at 782 .

${ }^{22}$ Commission Decision of 28 April 1999 establishing the European Anti-Fraud Office (OLAF) (OJ 1999 L136).

${ }^{23}$ House of Lords European Union Committee Strengthening OLAF, the European AntiFraud Office (House of Lords European Union Committee: London, 2004) at p.11.

${ }^{24} \mathrm{~J}$ Vlogaret, and M Pesta,(2008), 'OLAF fighting fraud and beyond' in S. Brown (ed.), Combating international crime - the longer arm of the law, Routledge, London, 77-87, at 77. 
discrepancies of EU and alleged staff misconduct, ${ }^{25}$ while external investigations relate to activities that occur outside the EU. The effectiveness of these investigations is limited due to OLAF's inability to independently initiate them, ${ }^{26}$ although it is permitted (though seemingly not encouraged) to assist other Member States by sharing information and financial intelligence. ${ }^{27}$

OLAF's performance has been limited due to the "shadow of UCLAF" ${ }^{28}$ and its relationship with Eurojust, the EUs Judicial Co-operation Unit. Eurojust was created to fight organised crime by improving the level of co-operation during investigations and prosecutions that occur in more than one Member State. ${ }^{29}$ The relationship has been described as "rather

${ }^{25}$ Ibid., at 79. For a discussion of the EU's anti fraud enforcement policy see White, S. (2010), 'EU anti-fraud enforcement: overcoming obstacles', Journal of Financial Crime, 17(1), 81-99.

${ }^{26}$ Ibid.

27 J Vlogaret, and M Pesta, (2008), 'OLAF fighting fraud and beyond' in S. Brown (ed.), Combating international crime - the longer arm of the law, Routledge, London, 77-87, at 78. One of the highest profile cases involving OLAF related to the Lesotho Water Project in South Africa. Following an investigation several people were convicted of bribery and corruption. See Sole $v$ The Crown C of A (Cri) 5 of 2002 (unreported). For a more detailed discussion of this case see Letsika, O. (2004), 'Creating a corruption-free zone through legislative instruments: some reflections on Lesotho', Journal of Financial Crime 12(2), 185191

${ }^{28}$ B Quirke. (2010), 'OLAF's role in the fight against EU fraud: Do too many cooks spoil the broth?', Crime, Law and Social Change, 53(1), 97-108.

${ }^{29}$ 2002/187/JHA: Council Decision of 28 February 2002 setting up Eurojust with a view to reinforcing the fight against serious crime, Official Journal L 063, 06/03/2002 P. 0001 0013. Pujas noted that it was "a temporary unit of judicial co-operation ... in charge of fighting serious transnational crime". See Pujas above, n 41 at 784. 
troubling", ${ }^{30}$ a position that worsened after Eurojust asserted that it saw OLAF as a competitor rather than a colleague. ${ }^{31}$ Furthermore, OLAF has no enforcement powers and only makes recommendations. ${ }^{32}$

The question of enforcement of EU anti fraud policies is then largely left to the EU Court of Justice through it case law. According to the well established case law starting with the Greek Maize ${ }^{33}$ case, Member States have to protect EU interest the same way as it protects national interests. Specifically, this case concerned fraud against the EU where the Court held that : "... the Member States must ensure that infringements of EU law are penalised under conditions, both procedural and substantive, which are analogous to those applicable to infringements of national law of a similar nature and importance and which, in any event, make the penalty effective, proportionate and dissuasive."

This long-standing case law on the equivalent protection and effectiveness of the system as developed by the EU Court of Justice has been

\footnotetext{
${ }^{30}$ B Quirke, (2010), 'OLAF's role in the fight against EU fraud: Do too many cooks spoil the broth?', Crime, Law and Social Change, 53(1), 97-108.

${ }^{31}$ House of Lords European Union Committee Strengthening OLAF, the European AntiFraud Office (House of Lords European Union Committee: London, 2004) at p. 12.

${ }^{32}$ Vlogaret, Johan and Pesta, Michal (2008), 'OLAF fi ghting fraud and beyond' in S. Brown (ed.), Combating international crime - the longer arm of the law, Routledge, London, 77-87, at 84.

${ }^{33}$ Case C-68/88 Commission v Greece [1989] ECR 1-2965, §24.
} 
complemented by a number of legislative instruments to fight fraud against the EU budget. The first relevant anti-fraud measures in this area were adopted in 1995 with the Convention for the protection of the financial interests of the European Communities (the PIF Convention). ${ }^{34}$

On that background, and a lot more recently in May 2015, the European Commission adopted a Proposal for a Directive on the fight against fraud to the Union's financial interests by means of criminal law'. ${ }^{35}$ The proposal is based on Article 325 TFEU and the fight against fraud against the EU's budget and at first instance this appears to be a significant development in the evolution of the EU's counter fraud strategy. The scope of the proposed Directive is limited to fraud committed against the financial interests of the EU. The Commission states that the framework is complemented by general Union criminal law measures for the fight against certain illegal activities particularly harmful to the licit economy, such as money laundering and corruption although not specific to the protection of the Union's financial interests - also contribute to their protection. ${ }^{36}$

\footnotetext{
${ }^{34}$ Convention of 26 July 1995 (OJ C 316, 27.11.1995, p. 49)

${ }^{35}$ Proposal for a Directive of the European Parliament and of the Council on the fight against fraud to the Union's financial interests by means of criminal law', COM(2012) 363 final, available at http://eur-lex.europa.eu/legalcontent/EN/TXT/PDF/?uri=CELEX:52012PC0363\&from=EN (last accessed 13 May 2016).

${ }^{36}$ In addition, Regulation (EC, Euratom) No 2988/95 sets out administrative rules for dealing with illegal activities at the expense of the Union's financial interests
} 
It could be argued though that this division between the Union's financial interests and the Member States interest does not make much sense when viewed in the light of the EU's market regulation powers. Of course, Article 325 TFEU only empowers the EU to fight fraud against its own budget. As will be shown below though with regard to the broader picture of market regulation and the construction of an AFSJ, the EU has largely transgressed the division of competence with regard to EU and Member States finances and fiscal powers. Therefore, it is suggested that the limitation set in Article 325 TFEU entails a rather cosmetic rule since the overall approach adopted by the EU seems not to be limited to fight fraud against the EU but also sets out to regulate the Member States as a result of the financial crisis.

\subsection{The proposed establishment of a European Public Prosecutor}

How would the situation then develop with the adoption of the European public prosecutor (EPP)? Indeed, should a EPP be established (Article 86 TFEU), such a prosecutor would have far-reaching investigative powers in the area of financial crimes. ${ }^{37}$ The prosecutor will be responsible for investigating, prosecuting and bringing to judgment, where appropriate in liaison with Europol, the perpetrators of and accomplices in offences

${ }^{37}$ See Proposal for a Council Regulation on the Establishment of the European Public Prosecutor's Office, COM (2013) 0534 final (July 7, 2013). 
against the Union's financial interests, as determined by the regulation provided for in Article 86 TFEU. The establishment of an EPP has however met some serious opposition. ${ }^{38}$ However considering the fact that at present 11 Member States have voted against the proposal through the yellow card procedure, it appears as if the enhanced cooperation mechanism will be the only venue available. The Commission has maintained essentially intact its proposal notwithstanding only the second use of the yellow-card subsidiarity procedure since the procedure's inclusion in the Lisbon Treaty. ${ }^{39}$ The main argument as presented by the Commission is that Eurojust and Europol have a general mandate to facilitate the exchange of information and coordinate national criminal investigations and prosecutions, but lack the power to carry out acts of investigation or prosecution themselves. According to the Commission, action by national judicial authorities remains often slow, prosecution rates on the average low and results obtained in the different Member States over the Union as a whole unequal. Based on this track record the judicial action undertaken by Member States against fraud may currently not be considered as effective, equivalent and deterrent as required under the Treaty. There is a fundamental flaw in the creation of a European Public

\footnotetext{
${ }^{38}$ See K Ligeti, (ed) Toward a Prosecutor for the European Union Volume 1 (Hart publishing 2012), G Conway, The Future of a European Public Prosecutor in M Fletcher, E HerlinKarnell and C Matera (eds), The European Union as an Area of Freedom, Security and Justice, (2016 Routledge forthcoming), M .L. Wade, 'A European Public Prosecutor: Potential and Pitfalls', 59 Crime, Law \& Social Change 439 (2013).

${ }^{39}$ See Conway, ibid.
} 
Prosecutor. It is difficult to separate on the one hand rules relating to investigations and prosecutions, at the EU level, and on the other hand, trials at Member State level. According to Peers, the Commission should have considered other possibilities of more limited measures to achieve the same objectives such as the harmonisation of the national prosecutions rules in this area. ${ }^{40}$

Indeed, Article 86(4) provides the opportunity for a future European Council to adopt a decision amending the competences of such a prosecutor to include serious crime with a cross-border dimension in the broader sense. The UK is interesting in this regard also. Should the UK stay in the EU, the UK European Union Act 2011 would require a referendum before it could agree to the UK accepting an EPP into UK law, although there are no indications the UK government wishes to opt-in to the proposed EPP. ${ }^{41}$

However, the establishment of an EPP has encountered some serious opposition with 11 Member States voting against its adoption through the yellow card procedure, it appears as if the enhanced cooperation mechanism will be the only avenue available. The Commission's proposal has essentially remained intact, notwithstanding the fact that the yellow-

\footnotetext{
${ }^{40}$ Steve Peers, EU Justice and Home Affairs Law (Oxford University Press 2011) 858-860.

${ }^{41}$ Conway, ibid 112
} 
card subsidiarity procedure has been used twice since the procedure's inclusion in the Lisbon Treaty. ${ }^{42}$ The main argument as presented by the Commission, is that Eurojust and Europol have a general mandate to facilitate the exchange of information and coordinate national criminal investigations and prosecutions, but they lack the power to carry out acts of investigation or prosecution themselves.

Whether Eurojust would simply be transformed into an EPP or would be used to assist the formation of an EPP is an open question on the basis of the phrasing in Article 86(1). As noted by Conway, it is an open question whether it would be useful to continue Eurojust as a separate prosecution branch. ${ }^{43}$ If an EPP is adopted by only some, at least nine for the enhanced cooperation to be triggered Member States, Eurojust would automatically remain for the non-participating Member States. ${ }^{44}$ This confirms that the result would remain messy and unclear to what extent the result would be 'effective' from enforcement perspective or 'transparent'.

A classic example of the EU's market powers to regulate financial crimes is that of the anti-money laundering area. Despite the Lisbon Treaty changes

\footnotetext{
${ }^{42}$ See Conway, ibid

${ }^{43}$ Conway, ibid.

${ }^{44}$ The European Commission accompanied its 2013 proposed Regulation on an EPP with a proposed Regulation to reform Eurojust: Proposal for a Regulation of the European Parliament and of the Council on the European Union Agency for Criminal Justice Cooperation (Eurojust), Brussels, 17.7.2013, COM/2013/0535 final - 2013/0256 (COD).
} 
and the increased legislative powers in criminal law as mentioned above the latest Money Laundering Directive is based on Article 114 TFEU.

\section{EU Anti-Money Laundering Action: The Fourth Directive}

The fight against dirty money has always been a high priority in the EU. Money laundering is by definition based on another crime termed a predicate offence, which gives rise to the laundering in question. In this respect, it should, however, be observed that there is an on-going debate in legal doctrine about the need to have a general definition of predicate offences in order to meet the legality requirement of strict construction in criminal law. It has been suggested that a problem with the 1991 and 2001 Money Laundering Directives was that they did not provide a definite list of predicate offences or the definition of a serious crime as the threshold for criminal activity. Itwas later superseded by another Directive in 2005 which introduced the risk based approach and also the fight against the financing of terrorism. ${ }^{45}$

\footnotetext{
${ }^{45}$ Directive 2005/60/EC OJ L309 (above $n$ 1). The Commission's own website is instructive: ec.europa.eu/internal_market/company/financial-crime/index_en.htm (last accessed January 2012).
} 
The European Parliament endorsed and agreed the Fourth Money Laundering Directive in May 2015. ${ }^{46}$ Member States are expected to implement the Directive's provisions by June 2017. The introduction of the new Directive seeks to improve the levels of AML and counterterrorist financing regulations in the EU. Another factor that influenced the introduction of the publication of the Directive was the publication of a new set of Recommendations by the Financial Action Task Force (FATF) in February 2012. ${ }^{47}$ The Fourth Directive seeks to "implement the recommendations issued by the FATF revised in February 2012, which set a global standard for combatting money laundering and terrorist financing". ${ }^{48}$ Kaetzler and Kordys took the view that "the European legislator ... exceeded some recommendations of the FATF and has included some additional European requirements. The stricter regime, extensive risk analysis and more requirements will involve more organisation and more work for obliged entities". ${ }^{49}$

\footnotetext{
${ }^{46}$ See also the European security agenda COM(2015) 185 final and proposal for a Directive on Combating terrorism and replacing Council Framework Decision 2002/475/JHA, $\operatorname{COM}(2015) 625$ final

${ }^{47}$ Financial Action Task Force Financial Action Task Force Recommendations (Financial Action Task Force: Paris, 2012).

${ }^{48}$ Kaetzler, J. and Kordys, T. 'Fourth Money Laundering Directive: increased risk management requirements' (2015) Comp. \& Risk, 4(5), 2-5

${ }^{49}$ ibid
} 
The Fourth Money Laundering Directive addresses a number of important issues that include the variation of the risk-based approach, the development of new rules that apply to electronic money, registers for ultimate beneficial ownership, no distinction between internal and external politically exposed persons, improved levels of cooperation between financial intelligence units and an improved sanctions regime. ${ }^{50}$ Additionally, Cogman noted that "key changes relate to firms' compliance obligations rather than to the substantive money laundering offences ... proposed amendments to know your client ... Controversial proposals for a public register of the beneficial owners of companies".$^{51}$

Within such a risk-based approach to money laundering, private actors, such as lawyers and banks, are expected to make risk assessments of their customers and divide them into low and high-risk. ${ }^{31}$ The rationale for actively engaging the private sector in the AML process is to make them collect the appropriate information. ${ }^{32}$ Therefore, this is commonly referred to as a 'risk-based approach' because private actors are required to pass on sensitive information based on a risk assessment of their clients. But the risk-based approach could also be seen in a broader governing context of

\footnotetext{
${ }^{50}$ ibid

${ }^{51} \mathrm{~S}$ Cogman, 'The devil is in the detail: the Fourth Money Laundering Directive in practice (2014) Journal of International Banking and Financial Law, 29(5), 308
} 
risk regulation at the EU (criminal law) level. Thus, the question of the governing of risk connects to the justification of EU legislative action in the first place. ${ }^{52}$

It must be pointed out that although the modifications to the risk based approach are welcome, they merely add to an already existing important part of the global AML. For example, the use of a risk-based policy has gained significant momentum since the FATF amended its Recommendations in $2003 .{ }^{53}$ The risk-based approach promotes a closer working relation between the FATF and the private sector. In July 2007 the FATF published its guidance on a risk-based approach which stated that: "By adopting a risk-based approach, competent authorities and financial institutions are able to ensure that measures to prevent or mitigate money laundering and terrorist financing are commensurate to the risks identified. This will allow resources to be allocated in the most efficient ways. The principle is that resources should be directed in accordance with priorities so that the greatest risks receive the highest attention". ${ }^{54}$

\footnotetext{
${ }^{52}$ E Herlin Karnell, The Constitutional Dimension of European Criminal Law (Hart 2012), ch 5.

${ }^{53}$ R. Booth, S. Farrell, G. Bastable and N Yeo. Money laundering law and regulation, Oxford: Oxford University Press, 2010, p.206.

${ }^{54}$ Financial Action Task Force, Guidance on the risk-based approach to combating money laundering and terrorist financing - high level principles and procedures, Paris: Financial Action Task Force, 2007, p. 2.
} 
Furthermore, the FATF has issues several guidance notes for the private sector that seeks to incorporate the risk-based approach. ${ }^{55}$ The use of a risk-based approach of the FATF is now contained in Recommendation 10 (formerly Recommendation 5$)^{56}$

In addition to the adoption of the risk-based approach by the FATF, the EU has also embraced this "key concept" ${ }^{57}$ However, it is important to note that the EU was initially skeptical of adopting such an approach. ${ }^{58}$ The Third Money Laundering Directive follows a very similar stance to that contained in Recommendation. ${ }^{5}$ For example, Article 6 states "but may determine the extent of such measures on a risk-sensitive basis depending on the type of customer, business relationship, product or transaction". The Directive also provides that customer due diligence comprises: "identifying, where applicable, the beneficial owner and taking risk-based and adequate measures to verify his identity so that the institution or person covered by this Directive is satisfied that it knows who the beneficial owner is, including, as regards legal persons, trusts and similar legal arrangements,

\footnotetext{
${ }^{55}$ This includes for example guidance for the financial sector, accountants, the legal profession and casinos.

${ }^{56}$ Financial Action Task Force, International Standards on Combating Money Laundering and the Financing of Terrorism: The FATF Recommendations, Paris, Financial Action Task Force, 2012, p. 59.

${ }^{57}$ Leong above, $\mathrm{n} 82$ at 147.

${ }^{58} \mathrm{~L}$. De Koker, 'Identifying and managing low money laundering risk: perspectives on FATF's risk-based guidance', Journal of Financial Crime, 2008, 16(4), 334-352.
} 
taking risk-based and adequate measures to understand the ownership and control structure of the customer". Therefore, the risk-based approach is "entrenched into EU law". ${ }^{59}$ The risk-based approach has also been adopted by the Basel Committee ${ }^{60}$ International Association of Insurance Supervisors ${ }^{61}$ and the International Organisation of Securities Commission, which shows that the $\mathrm{EU}$ is merely following the international trend here. ${ }^{62}$

As explained, the Fourth Money Laundering Directive seeks to establish an increased focus on risk assessment at the national level. Such a risk assessment is to be carried out in liaison with various agencies that should provide guidance for the Member States as to how to carry out risk assessments and where European Supervisory Authority plays a key role by also being asked to provide regulatory technical standards where needed for financial institutions to adapt their internal controls to deal with specific situations. Europol is the main player in the EU anti-terrorism tracking system. According to the Europol Decision, ${ }^{63}$ the agency is given a number

\footnotetext{
${ }^{59}$ Snowdon and Lovegrove above, $\mathrm{n} 34$ at 3.

${ }^{60}$ Basel Committee on Banking Supervision Customer Due Diligence for Banks, Basel: Basel Committee on Banking Supervision, 2001, section 2.2.4.

${ }^{61}$ International Association of Insurance Supervisors, Guidance paper on anti-money laundering and combating the financing of terrorism, Basel: International Association of Insurance Supervisors, 2004.

62 The International Organization of Securities Commissions, Objectives and Principles of Securities Regulation, Madrid: The International Organization of Securities Commissions, 2002.

${ }^{63}$ Council decision, establishing the European Police Office (Europol)
} 
of principal tasks including: (1) the collection, storage, analysis, and exchange of information and intelligence, and (2) the exchange of information concerning Member States about criminal offences. ${ }^{64}$ Moreover, as is stated in Article 88 TFEU, "Europol's mission shall be to support and strengthen action by the Member States' police authorities." It is then meant to act as a complementing authority, but it is becoming a primary actor. This is interesting (as well as problematic) from a democratic and accountability perspective. More specifically, Europol has been given substantial powers to shape procedural rules and conclude international agreements. It should be remembered that the Meroni Doctrine holds that only executive powers can be delegated from the EU institutions to agencies and their use must be entirely subject to the supervision of the delegating institution." ${ }^{65}$ Moreover, in the recent European Securities and Markets Authority (ESMA) case, ${ }^{66}$ Regulation No 236/2012 lay down a

\footnotetext{
(2009/371/JHA)

${ }^{64} \mathrm{C}$ Matera, The Influence of International Organisations on the EU's Area of Freedom, Security and Justice: A First Inquiry, in S Blockmans \& R Wessel (eds)., Between autonomy and dependence: the EU legal order under the influence of international organisations 269 Springer 2013.

${ }^{65}$ 9/56 and 10/56, Meroni \& Co., Industrie Metallurgiche s.p.a. v. High Authority [1957-1958] ECR 133, M Simoncini, Legal Boundaries of European Supervisory Authorities (ESAs) in the Financial Markets Tensions in the Development of True Regulatory Agencies (2015) YEL 1-32, see also P Schammo, 'EU day-to-day supervision or intervention-based supervision: Which way forward for the European system of financial supervision?' (2012) 32 Oxford Journal of Legal Studies 771, 789

${ }^{66}$ C-270/12, UK v Council and European Parliament, nyr.
} 
common regulatory framework with regard to the requirements and powers relating to short selling and credit default swaps to ensure greater coordination and consistency between Member States. The UK challenged this on the basis of that it not intended to authorise ESMA to take individual measures directed at natural or legal persons. The Court of Justice upheld the Regulation. It stated that "the EU legislature, in its choice of method of harmonisation and, taking account of the discretion it enjoys with regard to the measures provided for under Article 114 TFEU, may delegate to a Union body, office or agency powers for the implementation of the harmonisation sought. That is the case in particular where the measures to be adopted are dependent on specific professional and technical expertise and the ability of such a body to respond swiftly and appropriately. ${ }^{\prime 67}$

The outsourcing of responsibility in the fight against financial crimes has several dimensions. For example, Europol plays an increasing role as a global information hub and information center. The agency collects proceeds, retains and exchange data on unprecedented way. ${ }^{68}$ Most importantly, Europol was involved in the EU-US Agreement on the Terrorist Financing Tracking Programme. ${ }^{69}$ Accordingly, Europol assesses whether

\footnotetext{
${ }^{67}$ C-270/12, UK v Council and European Parliament, nyr.

${ }^{68} \mathrm{C}$ Harlow \& R Rawlings, Process and Procedure in EU Administration (Hart 2014) ch 10.

${ }^{69}$ (2010) L195/5, Agreement between the European Union and the United States of America on the processing and transfer of Financial Messaging Data from the European Union to the United States for the purposes of the Terrorist Finance Tracking Program.
} 
the data requested in any given case are necessary for the fight against terrorism and it's financing. In addition, the interpretation of the data allows Europol to pinpoint the areas, activities or populations, which are at risk and should be given priority in the fight against organized crime at the EU level. ${ }^{70}$ Yet the new powers granted to Agencies, as noted, raise familiar questions not only about the accountability of these actors but also about the desirability of outsourced enforcement powers from the perspective of judicial review. $^{71}$

Yet, the importance of agencies in EU lawmaking in general is far from new. Agencies are often said to represent a step in the direction of "better regulation." ${ }^{\prime 2}$ It appears to be unclear what exactly is the place of these agencies in the legislative context and their place in the AFSJ machinery. After all, areas such as medical authorization, electricity regulation, and heath regulation are spaces that have all been reformed in recent years and have offered examples of hybrid governance in terms of combining traditional EU legal instruments with network models relying on agencies

\footnotetext{
${ }^{70} \mathrm{H}$ Carrapiço \& F Trauner, "Europol and its Influence on EU Policy-making on Organized Crime", (2013), Perspectives on European Politics and Society 357.

${ }^{71}$ In the context of private actors and judicial review, A Harel \& Avihay Dorfman, Against Privatization as Such (forthcoming in Oxford Journal of Legal Studies 2016)

${ }^{72}$ See F Vibert, Better Regulation and the Role of Agencies, in BETTER REgULATION 387 (Stephen Weatherill ed., 2007).
} 
and new forms of governance such as comitology and open method coordination. ${ }^{73}$ This is all new in the AFSJ. While this paper will not delve into this complex debate, it is clear that the technocratic approaches pose difficulties from the democratic perspective as many issues such as medical regulation touch upon ethical issues that require democratic legitimation and accountability. Nevertheless, the prospect of adopting a technocratic model to the AFSJ, with regard to criminal law, should raise concern.

While the AFSJ agencies of Europol and Eurojust do not have direct regulatory enforcement powers, they are increasingly important players in the regulatory machinery within the AFSJ. As Monar points out, the Member States have kept the law enforcement powers and have not delegated such powers to the AFSJ Agencies, with the exception of Frontex in the area of migration law policies. ${ }^{74}$ Yet Europol has been given extended powers to supervise the EU crime-fighting agenda within the AFSJ. This has resulted in a complex relationship between AFSJ legislation and the role played by Europol in, for example, the financial tracking program and those legislative acts such as the Fourth Money Laundering Directive, discussed

\footnotetext{
${ }^{73}$ C Sabel \& J Zeitlin, Learning from Difference: The New Architecture of Experimentalist Governance in the European Union, 14 EUR. L. J. 271 (2008).

${ }^{74}$ See generally, J Monar, Experimentalist Governance in Justice and Home Affairs, in EXPERIMENTALIST GOVERNANCE IN THE EUROPEAN UNION 237 et seq. (Jonathan Zeitlin \& Charles Sablel eds., 2010).
} 
above, that are part of the internal market acquis. As for those instruments adopted within the internal market, the European Securities and Market Authority (ESMA) is responsible for any supervision. The ESMA contains a review clause that grants the Court of Justice the power to review the fines imposed by this agency. But it is not clear to what extent Europol and Eurojust can be held to account for their actions. ${ }^{75}$ The same holds true for the possible establishment of a European Public Prosecutor, which will have far-reaching powers to investigate EU financial crimes. ${ }^{76}$

As explained, the Fourth Money Laundering Directive seeks to establish an increased focus on risk assessment at the national level. Such a risk assessment is to be carried out in liaison with various agencies that should provide guidance for the Member States as to how to carry out risk assessments and where European Supervisory Authority plays a key role by also being asked to provide regulatory technical standards where needed for financial institutions to adapt their internal controls to deal with specific situations. Europol is the main player in the EU anti-terrorism tracking

\footnotetext{
${ }^{75}$ On Agencies, M Busuioc, D Curtin \& M Groenleer, Agency Growth Between Autonomy and Accountability: The European Police Office as a "Living Institution," 18 J. EUR. PUB. POL. 848-67 (2011). See also Pierre Schammo, The European Securities and Market Authority: Lifting the Veil on the Allocation of Powers, 48 COMMON MKT. L. ReV. 1887 (2011).

${ }^{76}$ G Conway, Holding to Account A Possible European Public Prosecutor: Supranational Governance and Accountability Across Diverse Legal Traditions, 24 CRIM. L. F. 371 et seq. (2013).
} 
system. As noted, according to Article 88 TFEU, "Europol's mission shall be to support and strengthen action by the Member States' police authorities." It is then meant to act as a complementing authority, but it is becoming a primary actor. The present paper can do no more than point out the complex interrelationship between the need to decentralize and make the Commission more effective, and basic concerns about the rule of law and legitimacy as well as accountability in criminal law.

\section{EU Financial Regulation and white collar crime: the UK experience} As noted above, market regulation in the area of financial crimes and consumer confidence were not a focus of the EU's initial responses to the financial crisis nor were they reflected on the international agenda. ${ }^{77}$ The UK is an interesting test case with regard to the EU's financial crimes agenda. For example, many commentators have stressed the 'gold plating' phenomenon, or over-implementation, in connection with the AML regime in the UK. ${ }^{78}$ For example, it has been pointed out that the notion of 'suspicion' in relation to the source of the proceeds of crime appears to have constituted a crucial theme in UK AML legislation. Thus, rather than

\footnotetext{
${ }^{77}$ Moloney Id.

${ }^{78}$ See e.g. V Mitsilegas, 'Global Standards in Domestic Legal Cultures: The Money Laundering Offences in English Law' in S Braum (ed), Droit Pénal Européen des Affairs (Berliner, Wissenschaftsverlag, 2009) 1.
} 
stipulating the requirement of 'knowledge' - that is, 'intent' — the UK legislator seems to rely on 'suspicion', which constitutes a lower threshold for prosecution on the criminal law scale. This is interesting, as the Directives in question refer to the requirement of 'knowledge' rather than an objective test consisting of 'having reasonable grounds to suspect'. This position can be contrasted with that adopted in the UK where successive financial regulatory agencies have been given the specific mandate to tackle and reduce financial crime. This was a very significant development in the UK and perhaps it could be simply classified as a 'common sense' approach given the historical links between the financial services sector and financial crime. The unique approach adopted in the UK resulted from the realistion that its financial services sector is continuously threatened by financial crime. This resulted in the partial merger of several important pieces of financial crime legislation with its financial services regulation. For example, by virtue of the Financial Services and Markets Act 2000 (FSMA 2000), the then Financial Services Authority (FSA) was given a statutory objective to reduce financial crime. ${ }^{79}$ The UK statutory definition of financial crime was as including 'any offence involving fraud, or dishonesty, misconduct in, or misuse of information relating to, a financial

\footnotetext{
${ }^{79}$ Financial Services and Markets Act 2000, s. 6.
} 
market or handling the proceeds of crime' ${ }^{80}$ The principal objective of the FSA has therefore been to focus on the anti-money laundering (AML) systems and controls that the regulated sector has in place. ${ }^{81}$ Under the FSMA 2000, the FSA makde rules in relation to the prevention and detection of money laundering. ${ }^{82}$ The rule-making powers of the FSA were originally contained in the Money Laundering Sourcebook, ${ }^{83}$ but these were detailed, burdensome and very similar to those in the Money Laundering Regulations $1993 .{ }^{84}$ The Money Laundering Sourcebook has been replaced by a principles-based approach in the Senior Management Arrangements, Systems and Controls (SYSC) part of the FSA's Handbook. ${ }^{85}$ The amended version provides that firms must have in place systems and controls which are appropriate for the firm to conduct its business. ${ }^{86}$ This includes: a

\footnotetext{
${ }^{80}$ Financial Services and Markets Act 2000, s. 6(3). For a more detailed discussion of the seminal definition of financial or white collar crime see E. Sutherland, 'The White Collar Criminal' (1940) American Sociological Review, 5(1), 1.

${ }^{81}$ A. Proctor, 'Supporting a Risk-Based Anti-Money Laundering Approach Through Enforcement Action' (2004) Journal of Financial Regulation and Compliance, 13(1), 10-14, 11. Members of the regulated sector are defined in the Financial Services and Markets Act 2000 (Regulated Activities) Order 2001 S.I. 2001/544.

${ }^{82}$ Financial Services and Markets Act 2000, s 146.

${ }^{83}$ Financial Services Authority, Money Laundering Handbook, (Financial Services Authority 2006). The FSA adopted the Money Laundering Regulation 1993 via the Financial Services and Markets Act 2000 Regulations (Relating to Money Laundering Regulations) 2001, S.I. $2001 / 1819$.

${ }^{84}$ S.I. 1993/1933.

${ }^{85}$ The FSA Handbook contains the FSA's legal rules and guidance on a wide range of measures and can be accessed from $<$ http://www.fsa.gov.uk/Pages/handbook/index.shtml>.

${ }^{86}$ Financial Services Authority, FSA Handbook (Financial Services Authority 2006, SYSC 3.1.1).
} 
requirement to carry out regular assessments of the adequacy of $A M L$ systems so as to protect themselves from being used to further financial crime ${ }^{87}$ the allocation of a director or senior manager with overall responsibility for establishing and maintaining an AML system; and, the appointment of a cer (MLRO). ${ }^{88}$ The SYSC regime seeks to provide the regulated sector Money Laundering Reporting Offiith an even higher degree of flexibility, which allows them to identify the risks and determine how they can best allocate their resources in areas which are most vulnerable. This approach seeks to encourage and enable the regulated sector to target their resources most appropriately on activities at risk from money laundering, thus reducing AML compliance costs

The most important tools that the FSA has in the fight against money laundering are its extensive investigative and enforcement powers. ${ }^{89}$ The FSA has the ability to require information from firms, ${ }^{90}$ to appoint investigators, ${ }^{91}$ to obtain the assistance of overseas financial regulators ${ }^{92}$

\footnotetext{
${ }^{87}$ Financial Services Authority, FSA Handbook (Financial Services Authority 2006, SYSC 3.2.6 C).

${ }^{88}$ Financial Services Authority, FSA Handbook (Financial Services Authority 2006, SYSC 3.2.6 $\mathrm{H}$ and $\mathrm{I})$.

89 J. Bagge, 'The Future for Enforcement Under the New Financial Services Authority' (1998) Company Lawyer, 19(7) 194-197, 195.

${ }^{90}$ Financial Services and Markets Act 2000, ss 165-166.

${ }^{91}$ Financial Services and Markets Act 2000, ss 167-168.

${ }^{92}$ Financial Services and Markets Act 2000, s 169.
} 
and provide appointed investigators with additional powers. ${ }^{93}$ Furthermore, the FSA has become a prosecuting authority in respect of certain money laundering offences. ${ }^{94}$ These powers apply whether or not the entity to be prosecuted is actually regulated by the FSA. ${ }^{95}$ The FSA also has the power to impose a financial penalty where it establishes that there has been a contravention by an authorized person of any requirement imposed under FSMA $2000 .{ }^{96}$ For example, the FSA has fined firms and MLROs who have breached its AML rules even where there was no evidence of money being laundered. ${ }^{97}$ This seems highly problematic from the perspective of fair trial and the presumption of innocence.

However, it is important to note that by virtue of the Financial Services Act 2012, the FSA was replaced by the Financial Conduct Authority and the financial crime statutory objective was removed and it is now associated with the FCAs consumer protection and market integrity objectives. ${ }^{98}$ The

${ }^{93}$ Financial Services and Markets Act 2000, s 172.

${ }^{94}$ The prosecutorial powers of the FSA were confirmed by the Supreme Court in $R v$ Rollins [2010] UK SC 39.

${ }_{95}^{9}$ Financial Services and Markets Act 2000, s 402 (1)(a).

${ }^{96}$ Financial Services and Markets Act 2000, s 206 (1).

${ }^{97}$ See Financial Services Authority, Press Release 'FSA Fines Alpari and its Former Money Laundering Reporting Officer, Sudipto Chattopadhyay for Anti-money Laundering Failings' (5 May 2010) <http://www.fsa.gov.uk/pages/Library/Communication/PR/2010/077.shtml> accessed 6 July 2011.

${ }^{98}$ Financial Conduct Authority 'Fighting financial crime', March 31 2013, available from http://www.fca.org.uk/about/what/protecting/financial-crimem accessed July 82013. Hereinafter ' $F C A$ '. 
FCA stated that "one of our objectives is to ensure the integrity of the markets ... a key part of that is ensuring that our markets operate honestly and that the firms we regulate understand, and manage, the financial crime risks that they face". ${ }^{99}$ Hill stated that "the FCA must also have regard to taking action in relation to financial crime. This will be a freestanding duty to take action in relation to any fraud, dishonesty, misconduct and handling the proceeds of crime" ${ }^{100}$ The regulator will continue to concentrate its resources towards maintaining "standards of conduct in the financial services industry". ${ }^{101}$ This means that the FCA will adopt a very similar approach towards the reduction of financial crime as that adopted by the FSA, namely that regulated firms must have appropriate systems and controls. Another legacy left by the FSA are the "the tools ... impose penalties for ... money laundering" ${ }^{102}$ Furthermore, the FCA will be expected to follow and further develop the FSA's credible deterrence strategy. ${ }^{103}$ This would involve the FCA continuing to "taking tough, targeted, effective and public action against misconduct perpetrated by firms and individuals". ${ }^{104}$ The influence of the EU is clearly illustrated by

\footnotetext{
${ }^{99}$ Ibid.

${ }^{100}$ Hill, C. 'Fund management update' (2013) Compliance Officer Bulletin, 104(Mar), 1-36, at 30 .

${ }^{101}$ Srivastava, A., Mason, I., Simpson, M. and Litt, M. 'Financial Crime' (2011) Compliance Officer Bulletin, 86(May), 1-23, at 9.

${ }^{102}$ Hill above, $\mathrm{n} 59$ at 30 .

${ }^{103}$ Srivastava et al above, $\mathrm{n} 62$ at 10.

${ }^{104}$ Hill above, n 59 at 30.
} 
the UK's continued adoption of the EU's money laundering and Directives. However, it is interesting to note that the limited influence of the EU on the enforcement strategy of the city regulator and it therefore appears that the UK is becoming the 'yard stick' on the enforcement of its financial crime objectives that the EU and other Member States could consider adopting.

\section{Fundamental rights? Challenges ahead beyond Europe}

While the discussion on the increased involvement of Agencies as monitors of financial crimes, pose well known questions about accountability they also pose more general questions of fundamental rights protection in the EU. Specifically, the discussion on the EU's regulatory endeavors to fight fraud and money laundering, pose some intriguing questions with regard to the adequate protection of personal data and applicable human rights protection. Indeed, there are some difficulties ahead for the EU and the Member States when it comes to ensuring a uniform standard of human rights protection. Although Article 52 sets of the Charter sets out the possibility to derogate from Charter rights when complied with proportionality, the applicable human rights standard needs to be sufficiently high. Specifically, Article 52(1) of the Charter sets out some important exceptions to the application of the Charter as a whole. This provision makes it clear that: 
Any limitation on the exercise of the rights and freedoms recognized by this Charter must be provided for by law and respect the essence of those rights and freedoms. Subject to the principle of proportionality, limitations may be made only if they are necessary and genuinely meet objectives of general interest recognized by the Union or the need to protect the rights and freedoms of others.

Yet there is reason to believe that the principle of proportionality as a guarantee of fundamental rights could have a significant impact in the area of the EU's suppression of financial crimes. A recent ground-breaking decision where the principle of proportionality was applied to strike down a legal measure on the retention of data is the Digital Rights case. The Directive 2006/24 ${ }^{105}$ authorized the gathering of data and far reaching surveillance mechanisms in order to ensure the effective fight against crime. The Court annulled the 2006 Data Retention Directive, which was aimed at fighting crime and terrorism and which allowed data to be stored for up to two years. It concluded that the measure breached proportionality on the grounds that the Directive had a too sweeping generality and therefore violated, inter alia, the basic right of data

\footnotetext{
${ }^{105}$ Directive 2006/24/EC of the European Parliament and of the Council of 15 March 2006 on the retention of data generated or processed in connection with the provision of publicly available electronic communications services or of public communications networks and amending Directive 2002/58/EC
} 
protection as set out in Article 8 of the Charter of Fundamental Rights. If the Court is to develop criteria for the increasing use of proportionality as a balancing principle in connection with the Charter, this will arguably confirm a more robust view of fundamental rights protection in AFSJ context.

As a follow up to the Digital Rights ${ }^{106}$ judgment, in Schrems, ${ }^{107}$ the Court asserted that the fact that US law allows US intelligence services to access the personal data of EU citizens without sufficient privacy safeguards breaches EU law. The Commission 'Adequacy Decision' 2000/520, adopted pursuant to Article 25 of the Data Protection Directive 95/46. Under Directive 95/46 allowed for the transfer of personal data to the US subject to the assessment of the Commission. Yet the Court held that when data is transferred to a third country this is only permissible where the third country in fact ensures an 'adequate level of protection'. The Court annulled the Directive on the ground that it provided for a far-reaching competence of US authorities to monitor data in breach of the Charter right of data protection and private life. These findings of limits sets to sweeping generality and domination in the EU law making are arguably readily translated to the EU financial crimes area. While the Court may be prepared to pass security focused legislation, if taking the digital rights

\footnotetext{
${ }^{106}$ Case C-293/12, Digital rights, judgment of 8 April 2014.

${ }^{107}$ C-362/14 Schrems v. Data Protection Commissioner Judgment of 6 October 2015.
} 
case seriously it requires a justification on behalf of the legislator requiring a specificity in the legislative approach.

\section{Conclusion}

This paper has critically assessed the EU and UK's current tactics in the fight against financial crimes by focusing on the EU's contemporary framework for fighting fraud and money laundering in particular. The objective of this paper was to chart the EU;s financial crimes agenda when discussing the fight against financial crimes in EU law and what external "bouncing" effects it may have. Additionally, this paper placed the EU's regulatory efforts in this area by locating it in the context of the current tide of global EU action. The study of EU financial crime poses difficulties as it demonstrates a very complex relationship between various actors and various legal bases and offers an example of non-market values read into Article 114 TFEU. While financial regulation and the fight against financial crime is still at the heart of the EU's "getting tough on crime" approach, the old internal market endeavors in this area are now much more complex than they used to be. ${ }^{108}$ In particular the extended powers granted to EU Agencies asks difficult question about democratic oversight in the AFSJ.

${ }^{108}$ See XX removed for anonymity 
The EU's approach towards money laundering can be contrasted with that towards the prevention of fraud. For example, the EU continues to introduce and require Member States to implement its money laundering Directive. The fourth Directive will be implemented by June 2017. This approach clearly places the onus on Member States to adhere to the international standards of the FATF and related UN money laundering conventions. However, the EU's position towards the prevention of fraud is contrary to the plethora of related legislative provisions aimed at tackling money laundering. For instance, there is no EU fraud Directive to impose basic obligations on Member States, the proposed Directive only applies to fraud committed on the finances of the EU. Furthermore, it appears that the EU is more concerned with fraud that is related it its own finances as opposed to fraud committed against its member states. The effectiveness of the EU's counter fraud measures is also restricted by the limited remit of OLAF, who are unable to commence an investigation or even instigate any criminal proceedings. It is still unclear whether there will be any establishment of an EPP, but the reluctance by the Member States demonstrates the sensitive nature of these questions and also highlights the difficulty of enforcement. While striping the EPP of its power but still granting some investigative authority, the only thing achieved is a half baled solution to a pressing problem of how to coordinate the EU's function as an active player in the game against financial crimes. The EU it to seriously consider tackling the increasing threat posed by fraud it is strongly 
recommended that it looks no further than its impressive AML policy in terms of an effective financial crime model. This comes with a price though. Concepts such as risk regulation and securitization seem to take us far from constitutional safeguards and concern for the individual. All this shows that risk regulation has become the new normal in AFSJ law, imported from the internal market but with a different kind of consequences. 